\title{
INCLUSIVE EDUCATION IN KAZAKHSTAN: SELECTED ISSUES
}

\author{
Gulnar Zholtayeva, Assel Stambekova, Anara Alipbayeva, Gulnur Yerzhanova, Zhetysu State \\ University named after I. Zhansugurov, gulnur_ppf@mail.ru
}

\begin{abstract}
Currently government of the Republic of Kazakhstan considers education of children with disabilities as one of the main priorities of education and society development in a whole. Thus, the most efficient means of achieving the ultimate goal for it is to reveal the most efficient ways of training of children with mental retardation. Inclusive or integrated education is becoming a powerful tool in this case if the range of educational institutions creates atmosphere which allows receiving high-quality education, correctional help and professional training. Every child and family is valued equally and deserves the same opportunities and experiences in meaningful ways. Inclusive education enables children with disabilities entering the society as full-fledged citizens who are capable of productive and independent life, building relationships and memberships with people around. As for Kazakhstan society the statistics shows: special educational services for the children with mental retardation are provided in 37 special kindergartens and 101 correctional schools, 240 special groups and 1098 special classes in compulsory schools. Moreover, nearly 10 thousand children are involved in home learning within individual study program. Since 2004 work on elaboration and publishing of Kazakhstani textbooks and educational-methodical complexes for special correctional educational organizations of 8 major kinds and types has been carried out. At the present time there are 56 medical-psychological-pedagogical rooms in the country. These institutions render medical-psychological-pedagogical support and social help to population how to diagnose and consult the children with disabilities
\end{abstract}

UDC Number: 376.42, DOI: 10.12955/cbup.2013.34

Keywords: integration, correctional training, development, disabilities

\section{Introduction}

Recently the tendency to approach general and special pedagogy has been explicitly growing as a result of a sharp increase of the children suffering from challenges in learning.

At the present stage pedagogical system of correctional-developing training of the children having obvious difficulties in study programs acquisition, adjustment to school and social environment is establishing. According to the 2008-2012 data of the Educational Department Office in Almaty region, number of children with disabilities has increased from 251 to 498 in Taldykorgan, otherwise stated, increasing the number of children belonging to the risk category of school, somatic and psychophysical disadaptation. Among them 50\% are the children having nervous and mental disorders since kindergarten younger groups' period. 
Also the number of elementary school students incapable of coping with the Standard School Program requirements has been gone up. According to the medical statistics, deterioration of students' health for 11 school years is one of the reasons for challenges in adapting them to school study loads. Tough conditions of school life lead to the sharp deterioration of physical and psycho-neurological health of a sick child. The problem of rendering assistance to children with challenges in learning has been considered by teachers for many decades (Shipitsyna, 2001). Adjustment classes of compensatory education, correction, pedagogical support, adaptation, health and others - all of these organizational forms indicate the search of conditions adequate to mental and physical students' capabilities.

\section{Inclusive education in Kazakhstan: Main strategies}

Social integration is considered to be the ultimate goal of the education of children with psychophysical developmental disorders: a graduate with a psycho-physical disorder shall enter the society as a full-fledged citizen capable of independent life, relationships with people and productive activities. From these positions, integrated (joint) training is the most efficient means of pursuing the ultimate goal in this case, if educational institutions create the conditions allowing receiving high-quality education, correctional help, labor training.

The government pays a great attention to education of the children with mental retardation. Thus, there are main data of teaching the children with disabilities in the Decree of the President No. 160 (2011):

Special education for the children with disabilities are introduced in 37 special kindergartens and 101 special needs schools, 240 special groups and 1098 special classrooms in comprehensive schools. Approximately ten thousand children are involved in home teaching within the individual program.

In 2007, 6.6 thousand students were involved into inclusive education in 241 schools within the country. Depending on the extent of disorders in psycho-physical development and cognitive capabilities, students are trained due to 3 options using the special educational programs and textbooks oriented to the different levels of cognitive development of the students with disabilities. In the republic work on elaboration, publication of Kazakhstani textbooks and educational and methodical complexes of special correctional educational organizations in 8 major kinds and types has been carried out since 2004; at the present time there are 56 functioning psychological-medical-pedagogical consulting offices that render medical-psychological-pedagogical assistance to the population in revealing, diagnosing and consulting the children with mental retardation.

Correctional and pedagogical support is being conducted in 156 inclusive education rooms for the preschool age children since their birthday, 123 psychological and pedagogical correction rooms, 15 convalescent centers, and 345 speech therapy units. Having organized in the country, complex diagnostics of developmental disorders and system of early correctional and pedagogical support allow only a third of all children with disabilities to be engaged in the educational process. The equal access to education for preschool children with limited developmental abilities is not fully provided.

Scope of the children with disabilities involved in the special study programs is only 41.4 percent. The multimedia equipment is from 35 to 60 percent in the special needs organizations. Provided equal rights of the children with disabilities and the disabled children to receive quality education are not realized in full measure; weak implementation of inclusive education is because of the insufficient awareness of the population and poor use of media to promote the ideas of inclusive (involved) education. 


\section{Problem of mental retardation forms classification}

Following this direction, the department of teaching and upbringing methods of Zhetysu State University named after Ilyas Zhansugurov is studying this problem within the grant project: "Integrated correctional-developing education of children with mental retardation in comprehensive elementary school". In the course of research group work the necessity for active organization of the integrated correctional-developing education of the children with mental retardation in comprehensive elementary school grades has been justified; directions of the integrated correctional-developing education of the children with mental retardation in comprehensive elementary school grades have been found out; the complex of conditions and requirements to educational process of the children with mental retardation in elementary school grades within the integrated correctional-developing education of comprehensive school, providing enhancement of efficiency in cognitive activity, has been revealed.

Having based on the study and analysis of the literature (Vlassova, 1973, Kovalyov 1985) on the research problem, the following classifications of mental retardation forms have been found out (Figure 1). Lebedinskaya's classification is the most widespread one (Lebedinskaya, 1982).

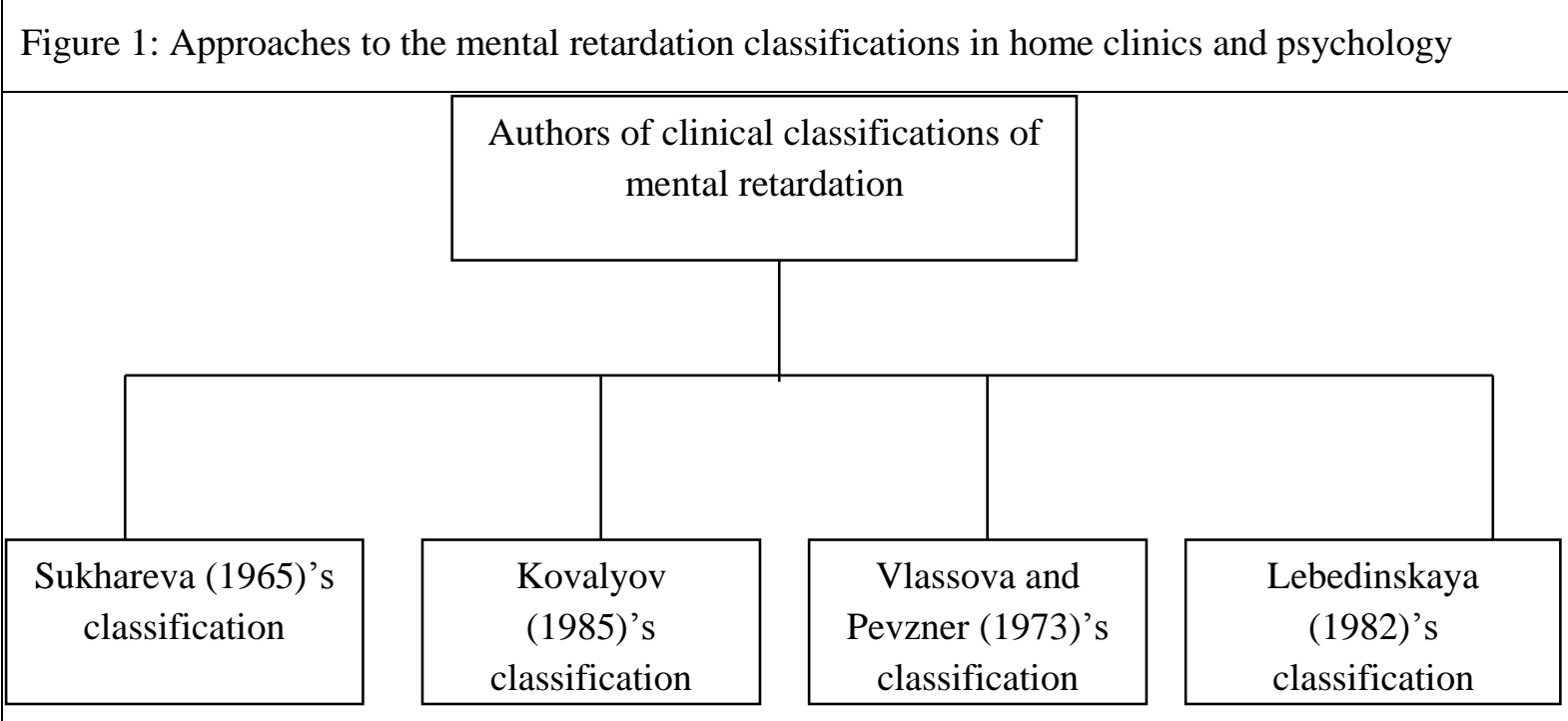

Source: Authors

Acquaintance with medical and pedagogical documentation of the district psychological-medicalpedagogical consulting office \#2 in Taldykorgan has showed that inflow of the children with disabilities (mostly with intellectual disorders and speech impairment) into mass school is observed (Table 1,2).

The disabled children and children with disabilities, taking into account their state of health, can be trained in secondary schools; however, inclusive education is not yet practiced in the country. Studies say that the society is not yet ready to transition to the inclusive education.

But in some regions it is carried out actively enough. So, for example: in Almaty the so-called adjustment classrooms are created within 24 secondary schools where the children with developmental disorders are grouped. In Taldykorgan the special needs (auxiliary) school for 150 children with 
intellectual disabilities has been merged with the mass school. Here classrooms place up to 25 - 30 children with special educational needs

Table 1: Information about the children with mental retardation having consulted in the District Psychological, Medical and Pedagogical Consulting Office \#2, Taldykorgan (mental retardation along with other diseases, school age 7-13)

\begin{tabular}{|l|l|l|l|}
\hline \multirow{2}{*}{} & \multicolumn{2}{|c|}{2010} & \multicolumn{2}{c|}{2011} & \multicolumn{2}{c|}{2012} \\
\cline { 2 - 4 } & \multicolumn{2}{|c|}{ Amount of children } \\
\hline Taldykorgan & 241 & 80 & 121 \\
\hline Tekeli & 34 & 13 & 14 \\
\hline Aksu & 39 & 16 & 28 \\
\hline Yeskeldi & 45 & 10 & 18 \\
\hline Karatal & 35 & 12 & 22 \\
\hline Kerbulak & 61 & 16 & 29 \\
\hline Koksu & 46 & 17 & 19 \\
\hline Total & 501 & 164 & 251 \\
\hline Source: Authors & & \multicolumn{2}{|l}{} \\
\hline
\end{tabular}

Table 2: Information about the children with disabilities who are registered in the District Psychological, Medical and Pedagogical Consulting Office \#2, Taldykorgan

\begin{tabular}{|l|l|l|l|l|l|l|}
\hline \multirow{2}{*}{ Years } & \multicolumn{2}{|c|}{ Categories of children } & \multicolumn{6}{c|}{ Child's age (years old) } \\
\cline { 3 - 8 } & & $0-3$ & $3-6$ & 6 & $7-18$ & $0-18$ \\
\hline 2008 & With mental retardation & 17 & 115 & 31 & 88 & 251 \\
\hline 2009 & With mental retardation & 18 & 56 & 23 & 66 & 163 \\
\hline 2010 & With mental retardation & 51 & 123 & 42 & 62 & 278 \\
\hline 2011 & With mental retardation & 63 & 179 & 47 & 132 & 421 \\
\hline 2012 & With mental retardation & 48 & 201 & 76 & 173 & 498 \\
\hline Source: Authors &
\end{tabular}

Today the successful functioning of comprehensive schools and any other educational institutions becomes impossible without high-skilled correctional and developmental work. The system of correctional training is a form of education allowing solving tasks of contemporary active assistance to the children with difficulties in learning and adaptation to school. This form is possible with the usual traditional organization of the educational process. It allows you to provide the best pedagogical conditions for children with difficulties in training and somatic and psychological-emotional health problems.

\section{Mental retardation forms and reasons of their appearance}

From Lebedinskaya's classification it follows that the integrated correctional-developing education of the children with mental retardation in comprehensive elementary school grades should be carried out in two areas: 
- integrated education of the children with mental retardation of a constitutional origin and with mental retardation of a cerebral-organic origin in elementary grades of a comprehensive school,

- integrated education of the children with mental retardation of a somatogenic origin and with mental retardation of a psychogenic origin in elementary grades of a comprehensive school.

Within mental retardation of the constitutional origin psyche's infantilism often fits infantile constitution with children's plasticity of facial expressions and motor skills. The emotional sphere of such kind a child is at an early stage of development corresponding to the mental makeup of a younger child: brightness and vividness of emotions; with prevalence of emotional reactions in behavior, gaming interests, suggestibility and lack of independence. These children never get tired of a game showing a lot of creativity and imagination, and at the same time they are quickly satiated by intellectual activity.

The reasons for the cerebral-organic forms of mental retardation in some way are similar to the causes of mental retardation. This similarity is determined by organic lesion of the central nervous system in the early stages of ontogenesis.

The predominance of more recent periods of destruction causes almost constant presence of signs of the nervous system damage along with the phenomena of immaturity. Therefore, in contrast with oligophrenia, which often occurs in the form of uncomplicated forms, there is almost always a set of encephalopathic disorders testifying to the nervous system damage in the structure of the mental retardation of cerebral and organic genesis. Cerebral-organic insufficiency determines the clinical and psychological structure of the mental retardation, in respect of immaturity both as an emotional and volitional spheres and cognitive activity. Emotional and volitional immaturity is presented in the form of the so-called organic infantilism. In contrast to the psyche of a younger child or demonstration of the constitutional infantilism, within the organic infantilism emotions are characterized by a lack of vivacity and brightness, certain primitiveness.

Rough suggestibility reflects the organic defect of criticism. With an obvious predominance of gaming interests over training, and in the game there is some monotony, lack of creativity and weakness of imagination (Belopolskaya, 2001).

Under the so-called somatogenic mental retardation conditions, the emotional immaturity is accompanied with long-lasting, often chronic diseases, heart malformations, etc. Chronic physical and mental fatigue hinders the dynamic forms development of activity, promotes the formation of such personality qualities as shyness, fear, lack of confidence in their abilities. These same properties to a large extent are determined by the regime of restrictions and prohibitions for a sick or physically weakened child. Thus, to the phenomena following the disease, the artificial infantilism is added caused by hypercare.

Mental retardation of the psychogenic origin is connected with the unfavorable educational conditions. Social genesis of this developmental anomaly does not exclude its pathological nature. As it is known that an early onset and long-term psycho-traumatic factor can cause the persistent shifts of neuropsychic sphere of a child underlying pathological development of his personality. So, pathological development of a person with mental retardation can be formed because of neglect, according to the type of mental instability: inability to inhibit their own emotions and desires, impulsivity, lack of a sense of duty and responsibility. Under the conditions of hypercare the psychogenic retardation of emotional development is revealed in the formation of egocentric sets, inability to willful effort or to work (Belopolskaya, 2001). 


\section{Psychological and pedagogical peculiarities of correctional and developmental education of the children with mental retardation}

At lessons the children with mental retardation are restless, do not follow the discipline requirements, in response to the reproaches they give promise to be better, but then forget about it. In the heart-toheart talk kids easily express their negative attitude to learning, do not hesitate to say that learning is boring and difficult or that they want to go for a walk or play a game (Belopolskaya, 2001).

As practice shows, at rendering aid to the children with difficulties in training pedagogues face many problems: they do not know the psychological peculiarities of children; medical diagnostics does not help them to understand the causes of poor progress and select appropriate methods of work; there are no special techniques, new technologies, and successful discoveries, as a rule, and few are being implemented in school practice

That's why early detection of the causes leading to students' poor progress and their disadaptation, and introduction of innovative teaching technologies can improve conditions for education of children of this category. This, in turn, will reduce the possibility of the child's nervous-mental, psychosomatic disorders as the effects of negative emotions and various forms of deviant behavior which are a kind of inadequate compensation for the poor progress in learning.

Today successful functioning of a comprehensive school and any educational institution becomes impossible without high-qualified correctional and developing work that is based upon the results of the complex diagnostics and new organizing methodic forms of activity.

Analysis of the current state of implementation of the integrated education in the Republic of Kazakhstan has revealed the following necessary conditions for the special organization of educational activity of children with mental retardation in the elementary classes on the basis of educational institutions:

- material and technical facilities of the integrated training process (special equipment, didactic materials, etc.),

- methodological software aimed at the integrated education of the children with mental retardation,

- staff training to correctional and pedagogical activity in the educational institutions under contemporary conditions,

- qualified correctional and developing work based upon the results of complex diagnostics and new organizing methodic forms of activity,

- introduction of innovative teaching technologies.

Regarding to the third condition - staff training: teacher of an integrated training class must have a teacher-defectologist degree or must attend not less than 500-600 hours of classroom training on the direction "Special (defectologist's) education", adding to this pedagogical practice of not less than eight weeks in a special needs school (classroom) and defense of a graduation thesis of the given direction.

Here it is appropriate to note that in the state educational standards of higher professional education of the third generation in the direction of "Special (defectologist's) education" (State Educational Standard of the Republic of Kazakhstan 6.08.061-2010, 2010) groups of cultural and professional 
competences were reported that should be formed in the future teachers - defectologists. For example, a teacher-defectologist must possess the professional competence as the ability to organize and implement psychological and pedagogical examination of persons with mental retardation with a view to clarifying the structure of a disorder and for the selection of individual educational path; willingness to provide advisory assistance to persons with mental retardation, their families and teachers on problems of training, development, family education, life and professional self-determination; ability to plan, organize and improve their own correctional and pedagogical activity and others.

In this connection the system of vocational education is facing increasingly complex challenges related to the achievement of a high leveled professionalism in persons providing the educational process. Graduates - defectologists must become the potential who are able to make a real and tangible contribution to the development of special education in Kazakhstan facilitating the implementation of the State Policy in the field of education.

The process of teachers-defectologists training is to be aimed at both traditional (special needs schools) and new types of educational organizations including integrated schools, kindergartens, convalescent centers, etc. with this regard a necessity to extend networks of basic organizations appears as professional practice basis for the students-defectologists.

Success of the special teacher training is connected with the following priorities in the field of education: fundamental nature of the content of education that ensures the versatility of mastered professional knowledge and aptitude to apply it practically; student-centered approach in education aiming at each student abilities development, taking into account individual interests and inclinations of students; transparency of the content of education; interactive character of education and others (Abdullina, 1991).

One should note that, in addition to the planned training of special education teachers in universities, it is necessary to intensify the creation of resource methodical centers on advisory assistance to teachers working in schools with special needs children on the basis of special (correctional) institutions in order to meet the growing needs of the society in the specialists-defectologists capable of performing professional duties, dictated by the time; conducting a course of teachers training to work in the inclusive classrooms and schools (Artemyeva, 2004); inclusion of the disciplines "Special Pedagogy", "Special Psychology", etc., in the curricula of all pedagogical specialties.

\section{Professional training of teachers for special needs schools}

Currently there are two ways to work with the children challenging in learning in the classes of correctional and developing training: The first way is to train teachers who have had some practical experience of working in a comprehensive school. The second way is to improve the university training. This tendency of improving the specialists training in a university has been supported in a range of higher education institutions in Russia. Didactic foundations of correctional and pedagogical training are components of vocational-educational system containing the unified bunch of aims, objectives, content and technologies if its implementation is in the integral pedagogical process of a pedagogical university.

Problems of teacher training has been studied in the numerous works of researchers (Abdullina, 1991). At the same time, the problem of correctional and pedagogical training of pedagogical universities students to work with younger children in the mental retardation classrooms is not found its proper 
expression, didactic bases of their training are still not disclosed, theoretical model is not developed, target program and process components of this training are not defined.

The purpose of correctional and pedagogical training of elementary school teachers should be not only the professional knowledge and skills molding in them, but also the formation of a high-skilled personality who possesses the integrated psychological-pedagogical thinking. The specialist, who works with children in this category, should be trained both in cognitive and personal plan for humanistic principles implementation in the course of interaction with these children, should be able to rely on the personal growth of a child, to take into account the individual peculiarities of his mental activity, create positive perspectives of his development, to organize a personality-developing educational environment that enables to identify and to realize the creative potential of a child in practice.

For the purpose of coordinating this direction it is necessary to develop the program-targeted component of students' training in the mental retardation classrooms.

Rebuilding of training courses allows to achieve the fundamental nature of their studying at the expense of involvement into the integrating courses "Correctional Pedagogy", "Integrated Correctional and Developing Education of Children with Mental Retardation in Elementary School Classrooms" aiming at mastering of certain invariant as a compulsory minimum of students training in the research area at the final stage of their training.

The type and structure of seminars and practical classes, used in the teachers training to work in the correctional classrooms, do not differ from the traditional ones. As the most optimal lesson form we should recognize the structure of the classes consisting of three interconnected components:

- discussion and analysis of theoretical character issues (speeches with messages, building up of support schemes, preparation of algorithms, etc.),

- pedagogical training (modeling of pedagogical situations, statement and solution of pedagogical objectives, molding of communication, persuasion, suggestion skills, etc.),

- pedagogical practicum (micro-teaching, micro-speeches, micro-conversations, micro-lessons, etc.).

Two special courses "Correctional Pedagogy", "Integrated Correctional and Developing Education of Children with Mental Retardation in Elementary School Classrooms" possessing the necessary methodical basis for effective implementation of the correctional and developing educational trajectory of students of Pedagogy and Methods of Elementary Education Departments to work with children in the correctional and developing training classrooms.

The special courses content can be used to organize educational training of future elementary school teachers for correctional and developing training of elementary school children and in the process of staff retraining and advanced training of the specialists in correctional pedagogy.

\section{Conclusion}

Thus, every student learns and uses the acquired knowledge in different way. However, the aim of education is concluded in achieving the definite determination of own importance by students, their concrete social status. 
Inclusion is an attempt to give students with disabilities confidence in their own abilities, to motivate them to learn along with friends and neighbors without any fear. "Special needs" children need not only support and special treatment; they need integral development of their abilities and aptitudes, progress in their activity.

Inclusion helps to implement the above mentioned aspirations of not only representatives of the younger generation with disabilities, and students, who, one way or another, differ from the majority. All of these younger representatives of society are in need of necessary modifications, different variants of presenting the information ways.

Pedagogical practice advocates for the inclusion of "special needs" children in the educational environment and for the successful study program acquisition by them. Such innovations encourage specialists and teacher of various profiles to work together for sake of welfare of extraordinary students. Inclusive education implies adoption of each child, flexibility of approaches to educational process.

\section{References}

Abdullina, O. A. (1991). Generalnyy pedagogicheskoy podgotovki uchitelya v sisteme vysshego pedagogicheskogo obrazovaniya [General pedagogical teacher training within higher pedagogical education]. Moscow, Russia: Prosveshcheniye.

Artemyeva, M. S. (2004). Integrirovannoye obucheniye: realii i perspektivy. Otchet o rezultatakh sotsiologicheskogo issledovaniya sredi predstaviteley vseobyemlyushchey shkoly v Chelyabinske [Integrated education: realia and perspectives. Report on the results of sociological research among comprehensive school representatives in Chelyabinsk]. Chelyabinsk, Russia: Abris.

Belopolskaya, N. L. (2001). Problemy psikhologicheskogo konsultirovaniyadetey s ogranichennymi vozmozhnostyami [Problems of psychological consulting of the children with disabilities].

St. Petersburg, Russia: Piter.

Government of the Republic of Kazakhstan. (2011). Postanovleniye Pravitelstva Respubliki Kazakhstan ot 19 fevralya 2011 № 160 [Decree of the Government of the Republic of Kazakhstan dated $19^{\text {th }}$ February 2011 No. 160]. Ukazom Kollektsiya Prezidenta i Pravitelstva № 20 [Decree Collection of the President and Government No.20]. Astana, Kazakhstan: Author.

Kovalyov, V. V. (1985). Klassifikatsiya i diagnostika psikhicheskikh zabolevaniy u detey i podrostkov [Classification and diagnostics of mental diseases of children and teenagers]. Moscow, Russia: Meditsina.

Lebedinskaya, K. S. (1982). Aktualnyye problemy diagnostiki zaderzhki psikhicheskogo razvitiya [Vital problems of diagnostics of mental retardation]. Moscow, Russia: Prosveshcheniye.

Shipitsyna, L. M. (2002). Umstvenno nepolnotsennyy rebenok v sem'ye i obshchestve [Ineducable child in a family and society]. St. Petersburg, Russia: Didaktika Plus.

Ministry of Education and Science of the Republic of Kazakhstan. (2010). Gosudarstvennyy obrazovatelnyy standart Respubliki Kazakhstan 6.08.061-2010 spetsialnosti 5B010500 Defektologiya [State Educational Standard of the Republic of Kazakhstan 6.08.061-2010 of the speciality 5B010500 - Defectology]. Astana, Kazakhstan: Author.

Sukharyova, G. Y. (1965). Klinicheskiye lektsii po psikhiatrii detskogo vozrasta (klinika oligofrenii) [Clinical lectures on psychiatry of child age (Clinic of oligophrenia)]. Moscow, Russia: Meditsina.

Vlassova, T. O. \& Pevzner, M. S. (1973). O detyakh s otkloneniyami v razvitii [About children with developmental disorders]. Moscow, Russia: Prosveshcheniye. 